\title{
Chips off the Old Block: An Old Fuel with a New Twist
}

\author{
by
}

\author{
Wendell P. Macintyre ${ }^{1}$
}

\begin{abstract}
The first settlers in the early 1700 's found almost all of Prince Edward Island covered by a magnificent virgin forest of sugar maple, yellow and white birch, beech, red oak and poplar blended with some spruce, fir, white pine, larch, hemlock and cedar. Nearly three hundred years of logging, land clearing and poor forest management have reduced the forest area by $50 \%$ and left the remaining forest largely a silvicultural slum. Recent federal/provincial agreements, however, have given rise to the expectation that P.E.I. will once again become self-sufficient for wood and that use of forest biomass will greatly reduce the dependence on oil for energy.
\end{abstract}

\section{Résumé}

Les premiers arrivants du début du 18 ième siècle trouvèrent presque toute l'lle du Prince Edouard couverte d'une magnifique forêt vierge composée d'érable à sucre, de bouleau jaune, de bouleau à papier, de hêtre, de chêne rouge et de peuplier auxquels s'ajoutaient quelques épinettes, sapins, pins blancs, mélèzes, pruches et cèdres. Près de 300 ans d'exploitation, de défrichage, et de pauvre aménagement forestier ont réduit la superficie forestière de $50 \%$ et ont laissé la forêt résiduelle en très mauvais état sylvicole. Les récentes ententes fédérales provinciales ont toutefois laissé entrevoir quelques possibilités que III.P.E. redevienne à nouveau autosuffisante en terme de matière ligneuse et que l'utilisation de la biomasse forestière réduise de façon appréciable sa dépendance énergétique envers les produits pétroliers.
The area of Prince Edward Island is 575000 hectares, or 1.4 million acres, of which $48 \%$, or 700000 acres is forest land. For almost three hundred years, Islanders used wood to build houses, barns, places of business, fishing boats, sailing boats, heating and cooking. The first pioneers who came to Prince Edward Island from France in the early eighteenth century cut timber to erect the first permanent settlement on the Island; this was Port La Joie, built in 1720, just across the harbor from present-day Charlottetown. In 1739, there were only 440 settlers on Prince Edward Island, and they must have been charmed by the prime virgin forest, dominated by hardwoods - beech, yellow birch, white birch, sugar maple, red oak, poplar and willow - blending with some fir, spruce, larch, white pine, hemlock and cedar. As other immigrants arrived, the Scotch, Irish and English, the entire population indiscriminately logged the timber lands to satisfy their heating, construction and boating needs.

The early 1800's on Prince Edward Island was the era of sailing ship construction. This period was known as the "Golden Age of Sail," when about forty-five hundred ships were launched at hundreds of shipyards around the Island. Prince Edward Island quickly gained an international reputation as a major shipbuilding centre in the New World.

Associate professor of English at the University of Prince Edward Island, 550 University Avenue, Charlottetown, PEI, C1A 4P3.
Stately, strong schooners, barques and brigantines slipped out of the hands of their architects, and plied their way through the Atlantic to New England and Europe with potatoes, grain, and lumber which the ship owners sold for a handsome profit. Occasionally, even the sailing ships, which carried the produce, would also be sold in foreign ports. However, in the 1880 's, steel boat hulls gradually replaced their wooden predecessors, retarding and eventually halting the sail boat industry on Prince Edward Island. Simultaneous with the decline of this industry was the disappearance of the virgin forests. By 1900, the Island forest lands might well have resembled a ghostly wasteland, with rejected species left to mourn the demise of earlier silvan nobility.

Other misfortunes also contributed to forest depletion on Prince Edward Island. Disastrous forest fires over many years since the eighteenth century destroyed thousands of acres of maturing and promising forest, and land clearing for agriculture, heavy logging for lumber and pulpwood accelerated the decline of Island forests. All these catastrophes led to the virtual disappearance of the local forest industry, with a consequent loss of employment, declining property values, the importation of lumber, and a growing dependence on coal and oil for energy.

The twentieth-century innovations, such as oil furnaces, electric water heaters, kitchen ranges, and other modern conveniences became popular among the people of Prince 
Edward Island. There were also relatively inexpensive energy alternatives in the mid 1900's. This, unfortunately, is no longer true, and it explains the vigorous search for more economical sources of energy.

The decline in forests was the prelude to the rapid growth of agriculture on the Island. In 1920, 767000 acres, or $55 \%$ of the total land area of Prince Edward Island, was under cultivation. Small family farms became prosperous and contributed effectively to the strength and vitality of Island communities. Living and working close to nature, the rural people embraced and practised the simple virtues that described country living. However, mechanized farming became the vogue towards the middle of the century. The aftermath has been everywhere apparent. Hundreds of small farms have been abandoned, and by 1985,150000 acres of this farm land has reverted to forest. This might seem like an encouraging situation for forestry, but unfortunately, although Island forests have grown in quantity, their quality has been declining steadily. Decades of poor management, unsystematic cutting, non-replacement of felled trees, a general indifference to - or even ignorance of - the fundamental principles of forestry - all of these have contributed to making the Island forests into a "silvicultural slum."

Forest potential exists, however, for Prince Edward Island to become self-sufficient in hardwood and softwood, Christmas trees, maple syrup products, and heating energy. The forest land base is adequate for softwood and hardwood lumber requirements. There is a limited supply of good hardwood and softwood timber, but much remains to be done to make Island forests more productive, both in quantity and quality. Nevertheless, one can be hopeful because the forest soils are good and tree growth is rapid. In sheltered locations on good soils, tree growth in Prince Edward Island may be equal to that of any in eastern Canada, but it depends on the particular site. In much of P.E.I., constant wind from the sea tends to limit the height growth of trees.

The 700000 acres of forest land on Prince Edward Island are potentially productive and easily accessible. Ninety percent of this forest area, or 630000 acres, is owned by 16000 private woodlot owners; $10 \%$ or 70000 acres is Crown forest, most of it owned by the provincial government. The average private wood lot is less than 50 acres; however, 200000 acres of this privately owned forest land is of poor quality, due largely to poor management. Moreover, $70000^{2}$ acres of forest suffers from spruce budworm. There are some other insect problems in plantations, but these do not affect large areas.

\section{Forest Arrangements}

In the mid 1900's, a series of remedial measures affecting Island forests started to emerge. In 1951, a Forestry Division of the Prince Edward Island Department of Industry and Resources was established. As a result, the provincial government launched a program of forest renewal, involving thinning, removal of fallen trees, and planting of seedlings. In 1952, Prince Edward Island signed a forestry agreement with the federal government, a 50-50 cost-shared program totalling $\$ 25000$ a year. The main thrust of this accord was reforestation, and between 1952 and 1976, the Forestry Division planted 4.25 million seedlings throughout the province. In 1969, a 15-year Comprehensive Development

${ }^{2}$ Canadian Forestry Service, 1985. Forest Insect and Disease Survey.
Plan, aimed at the social and economic improvement of Prince Edward Island, was arranged between the federal and provincial governments. Not until 1974, however, was a longrange forest management program started. Subsequently, the cost of most of the forestry programs was shared on a 90-10 federal/provincial basis. In 1980, seedling production facilities on Prince Edward Island were improved with the erection of greenhouses and a bareroot nursery in West Royalty, just west of Charlottetown. In this same year, a private land management assistance scheme was initiated to encourage interest in forest management among the private woodlot owners. As of 1985, thirteen hundred of these woodlot owners had become involved in the plan. The Prince Edward Island Land Development Corporation, a provincial agency that oversees the quantity and quality of both forest and farm land in the province, provided a Crown Timber reserve for development by the Forestry Division. By 1982, 1000 hectares or about 2300 acres of this Crown Timber land had been reforested. About this same time, a biomass inventory the first in Canada, was undertaken. Tree biomass includes the stem, branches, bark, needles and leaves, all of which can be converted to heating energy, or a combination of energy and some higher-value product, such as sawlogs.

In July, 1983, a federal/provincial Forest Resource Development Agreement was initiated. This was a five-year venture costing $\$ 20$ million, arranged on the basis of 68:32 federal/provincial funding. The program is designed to improve the Island's 700000 acres of forest, and its goal is to develop healthy, productive forests that will bring maximum economic benefits to Prince Edward Island. Sixteen thousand private woodlot owners, who own $90 \%$ of the Island's forest lands, are to be encouraged to adopt modern management techniques. The immediate aim is to have 1500 forest management agreements, representing 105000 acres, or $16.3 \%$ of all forest land, signed with private lot owners, between 1983 and 1988. On Crown forest land, the principal activity will be timber stand improvement (Table 1).

It was expected that about 1400 acres of Crown forest land would be improved annually. As a result of these arrangements, the growth and quality of timber stands on Prince Edward Island will be improved by thinning, site preparation, planting, and road construction.

The Forest Resource Development Agreement is expected to bring other benefits as well (Table 2). The more than 50 sawmill owners on Prince Edward Island will hopefully benefit and, eventually, the Island may become self-sufficient in lumber production. As of 1985, Prince Edward Island was spending $\$ 4.5$ million annually on imported lumber. Ultimately, the sawmills on the Island should produce 20 million fbm of sawn and processed lumber annually. The wood fuel industry should double the 1983 consumption of 70000 cords a year, to the equivalent of 140000 cords a year by 1988 in the form of roundwood and chips. This should reduce annual fuel oil imports by 111000 barrels. Direct employment in the forest industry - in forest management - will increase. The employment figure of 400 person-years in 1983 should reach 600 person-years in 1989 . Related benefits flowing from the Forestry Agreement should include increased income and employment opportunities from subsidiary industries, such as Christmas trees, furniture manufacture, crafts, and maple syrup products.

Other benefits of the Forest Resource Development Agreement, affecting both private and Crown-owned forest lands, should be: greater public awareness about forests and 
Table 1. Provincial forest management objectives. ${ }^{3}$

\begin{tabular}{lrrr}
\hline & $\mathbf{1 9 8 2}$ & $\mathbf{1 9 9 0}$ & $\mathbf{2 0 0 0}$ \\
\hline Stand improvement (ha/yr) & 300 & 2000 & 4000 \\
Reforestation (ha/yr) & 500 & 1200 & 800 \\
Site preparation (ha/yr) & 450 & 800 & 800 \\
Seedling production & 100000 & 1500000 & 1750000 \\
$\quad-$ bare root & 1100000 & 1500000 & 1750000 \\
- contrainerized & 20000 & 100000 & 150000 \\
Area under management (ha) & &
\end{tabular}

Table 2. Expected impact of the Forest Development Program on wood production and employment.

\begin{tabular}{|c|c|c|c|}
\hline & 1982 & 1990 & 2000 \\
\hline \multicolumn{4}{|l|}{ Harvesting } \\
\hline - clearcut (ha) & 2000 & 3000 & 3500 \\
\hline - commercial & 150 & 1000 & 2000 \\
\hline Production - roundwood (ODT) $)^{*}$ & 120000 & 150000 & 125000 \\
\hline Production - biomass (ODT)* & 3500 & 150000 & 375000 \\
\hline Lumber production (MM fbm) & 16 & 22 & 25 \\
\hline Lumber production ( $\%$ graded) & 0 & 25 & 25 \\
\hline Employment (person-years) & 400 & 600 & 750 \\
\hline
\end{tabular}

- Oven-dried tonne equivalent to 1 green cord.

forest management arising from courses in the school curriculum dealing with forestry; adult education services; displays and demonstrations of modern forestry equipment and techniques; land reclamation - the reforesting of wet lands and poor lands; weed and insect control; an emphasis placed on environmental and ecological balance; the continuing development of the biomass experiment; seedling production; and the effective use of the mass media as a means of focusing attention on forests and forestry on Prince Edward Island.

The Agreement has had a powerful impact on the people of Prince Edward Island. It has engendered lively interest in, and greater respect for, the Island's forest lands. Directly or indirectly involved in the program, all Islanders share in the social and economic enhancement that forest renewal has generated. Their congenital Island patriotism is further enhanced by forecasts of ultimate self-sufficiency in lumber and wood fuel. A feeling of optimism has stimulated an aggressive determination among the people to minimize their dependence on imported oil and electricity for heating. This determination was given encouragement by a momentous announcement in 1984.

\section{Alternate Energy Development Agreement}

In June, 1984, an Alternate Energy Development Agreement was signed between the federal and provincial governments. This was a five-year \$10-million plan, with a cost-sharing of $80: 20$ federal/provincial. It was a logical sequel to the Forest Resource Development Agreement of 1983, which promoted forest improvement and development.

Prince Edward Island has the highest energy costs in Canada, with $85 \%$ of its heating energy coming from oil or from electricity purchased from off the Island. Increasingly aware of their traditional enslavement to foreign sources of energy, Islanders recognized the desirability of energy selfsufficiency. They were convinced that Island forests could help them achieve this goal (Table 3 ).

The objectives of the Alternate Energy Development Plan were to reduce Prince Edward Island's reliance on imported oil, to intensify the biomass conversion experiment, to lower expenditures for purchased oil, and to develop energy-related expertise and technology (See Figures 1 and 2). Five initiatives were organized under the Plan. These included a Biomass Conversion Program, funded federally (\$6.6 million),

\section{Table 3. Assumptions underlying the stated provincial forest management objectives:}

1. There are 276000 hectares of forest land on Prince Edward Island; by year $2000,60 \%$ of the total forest land will be managed on a sustained yield basis.

2. Energy generating from wood-fired units will total $20 \mathrm{Mw}$ by 1990 and $40 \mathrm{Mw}$ by 2000

3. Natural gas will not become available on P.E.I. by the year 2000 .

4. Clearcutting (conventional) will produce $60 \mathrm{ODT} / \mathrm{ha}$. Commercial thinnings (full biomass utilization) will produce 50 ODT/ha.

5. Industrial/commercial heating will be $30 \%$ wood-fired by 1990 and $60 \%$ by 2000 ; residential heating will be $70 \%$ wood-fired by 2000 .

6. The ratio of conventional to full-utilization harvesting (area) will be $1: 1$ by 1990 and $1: 4$ by 2000 .

7. The ratio of roundwood to biomass production (ODT) will be $1: 1$ by 1990 and $1: 3$ by 2000 .

8. $50 \%$ of 10 -year-old clearcuts will be cleaned annually by 1990 and $66 \%$ by 2000 .

9. The ratio of acreage of hardwood to softwood harvest through the planning period will be 1:2.

10. The use of proper harvesting techniques will encourage natural regeneration and make it unnecessary to plant on most of the hardwood cutovers. It is estimated that $60 \%$ of clearcut softwood areas and $10 \%$ of clearcut hardwood areas will require artificial reforestation.

11. The requirement for mechanical site preparation on cutover lands will not increase between 1990 and 2000 because of a proportional increase in the level of whole-tree harvesting.

12. The trend in lumber production will be toward increased utilization of small diameter logs.

13. All products harvested will be sorted for the highest end-use value.

${ }^{3}$ See Table 3 for the assumptions underlying these objectives. 
SOURCE OF ENERGY

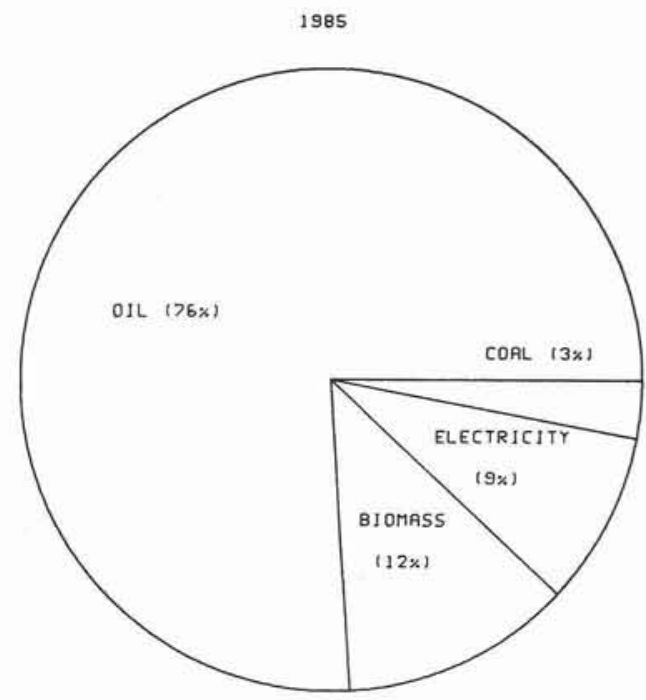

Figure 1. Prince Edward Island's present sources of energy.

which would encourage companies, institutions, and rural communities to convert whole-tree chips, straw, wastes and garbage into heating fuel. Second, a Wood/Biomass Product Development Program, federally funded ( $\$ 1$ million), which would try to develop an affordable residential wood chip furnace suitable for Island conditions. Third, the provincial government launched a Wood Supply Systems Initiative Program at a cost of $\$ 1.1$ million to develop forest harvesting, processing, and transportation systems. These would increase the availability of wood fuel. Fourth, the provincial government allocated $\$ 625000$ for a Charlottetown District Heating Plant Study. This study was to examine the feasibility of constructing a wood chip heating plant for Charlottetown and the immediately adjoining areas. Finally, the federal and provincial governments jointly began a study: Energy Alternatives for Prince Edward Island. Funded \$100 000: $\$ 24000$ federal/provincial, this study would estimate the costs of a selected mix of energy options for Prince Edward Island.

Results accruing from the Alternate Energy Development Plan should include: more carefully managed and increasingly productive forest lands; on the part of local
SOURCE OF ENERGY

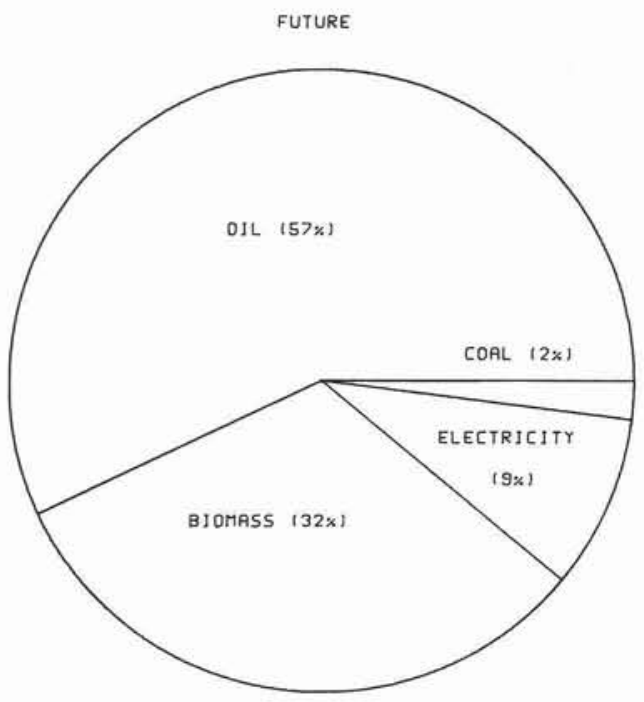

Figure 2. Prince Edward Island's expected future sources of energy.

businesses, institutions, and industries, an opting for wood as a more economical source of energy; a more encouraging economic outlook for private woodlot owners; employment for Islanders; and a new spirit of energy independence.

Already in 1986, three schools, a community hospital in Montague, a correctional institute in Charlottetown, the provincial government administrative complex, three senior citizens' manors, the Univeristy of Prince Edward Island, and the new Atlantic Veterinary College on the University campus, all have, or will have, wood chip heating plants. Similar types of heating systems are planned for the downtown centres of Charlottetown and Summerside. The Queen Elizabeth Hospital, built in the early 1980 's, and the Island's largest, is heated from a plant that uses a mixture of municipal garbage and wood chips. To elaborate on only one of these "conversion stories," the community hospital in Montague uses 2000 green tonnes of whole-tree wood chips annually. The hospital's heating system is a 90 horsepower boiler that displaces 70000 gallons of fuel oil a year, resulting in a saving of about $\$ 30000$ a year.

The future for Prince Edward Island looks bright — and warm 